\title{
Niech James żyje: z Jackiem Dehnelem o przekładzie The Turn of the Screw
}

DOI: http://dx.doi.org/10.12775/LC.2017.020

Dorota Guttfeld: The Turn of the Screw to powieść na tyle znana, że doczekała się nawiązań w innych utworach. Czy tłumacząc Dokręcanie śruby, miał Pan w pamięci któreś $\mathrm{z}$ takich nawiązań albo adaptacji? Czy staral się Pan, by nowy przekład był $\mathrm{z}$ nim „kompatybilny”?

Jacek Dehnel: Przede wszystkim opera Brittena! Cała skonstruowana jest na zasadzie „dokręcania śruby" tonacji, od początku do końca robi cały obrót, z numeru na numer. Z powtarzającym się co scenę motywem dwunastotonowym, coraz bardziej obsesyjnym i bolesnym. Zresztą, powiedzieć muszę, dopiero co The Turn of the Screw została wystawiona w Szczecinie i choć w polskich przewodnikach operowych figuruje jako Obrót śruby, to tam wybrano mój tytuł, bo twórcy spektaklu uznali, że to on właśnie najlepiej oddaje intencje twórców, Jamesa i Brittena. A i ładnie schodzi się z ich pomysłem inscenizacyjnym, czyli zastosowaniem obrotowej sceny, która również ma „dokręcać”. Łatwo zrozumieć, że żadne kleszcze lęku tego nie załatwiają.

Do tytułu jeszcze wrócimy, a jak Pan sobie radził ze stylem Jamesa? Jego zdania są długie i zawiłe, przerywane piętrowymi wtrąceniami. Co z tego stylu bezwzględnie starał się Pan zachować, a co Pana zdaniem można bylo uprościć?

Niczego nie można uprościć. Jak chce się prościej, to tłumaczy się innego pisarza. Nie widzę powodu, by polskiemu czytelnikowi dawać jakiś digest $\mathrm{z}$ Jamesa, wersję, bo ja wiem, ułatwioną, ad usum delphini. Język Jamesa jest przedziwny, chciałbym powiedzieć szalony, ale w tym wszystkim nie ma szaleństwa, to jest jakieś, ocierające się niekiedy o groteskowość, przerafinowanie, osobliwy stosunek do zdania, skądinąd niekiedy mi bliski, w którym nic nie jest pewne. Niby orzekamy jakąś kwestię A, ale równocześnie czynimy do niej zastrzeżenie w postaci wtrącenia $\mathrm{B}$, a do tego z kolei jakąś wątpliwość w postaci dodatku C, i tak dalej. Uprościć to? Jak, przepraszam? Przez usuwanie, czy przez jakieś pokawałkowanie, że najpierw A, potem B, wreszcie C? To już by nie był James. 
Ten specyficzny język potęguje niedookreśloność opowieści guwernantki. Choć niejednoznaczność zwykle jest sytuacyjna - tworzą ją urywane dialogi, luki w opisach, niejasne obserwacje - czasem jednak warunkuje ją właśnie materia języka, wieloznaczność gramatyczna czy semantyczna. Czy pamięta Pan jakieś problemy z przekładem niejednoznaczności tego drugiego typu?

Och, mnóstwo, tam się roi od pułapek. Ale James ma to do siebie, że pisze niesłychanie zawile, jego tekstów nie tłumaczy się z angielskiego, tylko z jamesowskiego, podobnie jak Brunona Schulza nie tłumaczy się z polszczyzny, na przykład, tylko ze specyficznego języka Schulza. Owszem, pani Grose mówi w nieskomplikowany raczej sposób, ale myśli narratorki to jest niesłychana plątanina przedziwnie połączonych ze sobą słów, terminów osobliwych lub przestarzałych niekiedy już w czasach Jamesa, dziwnych złożeń, które wyglądają jak rzadkie idiomy, ale po długich kwerendach słownikowych i googlowych okazuje się, że występują tylko w tym jednym jedynym tekście. Nie potrafię teraz przywołać żadnego przykładu nie tylko dlatego, że minęło już trochę czasu od tej pracy, ale przede wszystkim dlatego, że było to tak nagminne. Pamięć nie zarejestrowała konkretnego problemu, tylko jakiś długi mozół i niepewność.

Jeżeli niejednoznaczność tej opowieści jest tak dojmująca, czy uważa Pan, że jeśli nadarza się okazja, ten aspekt też można „dokręcić”? Czy były jakieś momenty w przekładzie, kiedy celowo rozmył pan znaczenie, bo język polski na to pozwalał?

Wydaje mi się, że tłumacz jest jednak sługą autora, a nie jego przemądrzałym nauczycielem - i nie powinien go poprawiać. Mówimy wszak o autorze wybitnym, a nie o gałganie. Wiadomo, że języki nie przystają do siebie, więc często rzeczy bardziej jednoznaczne w jednym będą mniej jednoznaczne w drugim, ale w skali całego tekstu to się jakoś tam, myślę, uśrednia - i należy, jak sądzę, starać się, na ile to możliwe, uzyskać taki balans między jednoznacznością a wieloznacznością, jak zaplanował to autor.

$\mathrm{Z}$ drugiej strony, niektóre sprawy dla współczesnych Jamesa mogły pozostać niedopowiedziane, ale dla wielu dzisiejszych czytelników robią się już zupełnie nieczytelne. Czy zdecydował się Pan w którymś miejscu na jaśniejsze niż w oryginale wyłożenie jakichś kwestii?

W jednym jedynym miejscu rzeczywiście stoczyłem z samym sobą dość długą walkę w ostatniej scenie, w której Miles, na chwilę przed śmiercią, wyjawia wstydliwy sekret szkolny, jakieś szeptanie nieprzyzwoitych, jak się możemy spodziewać, słów kolegom w szkole. Spytany, czy było ich wielu, odpowiada: „Those I liked”. I tu właściwie dochodzimy nie tylko do nieprzetłumaczalnej dwuznaczności, bo w polszczyźnie „ci, których lubiłem” i „ci, którzy mi się podobali” to jednak dwie zupełnie różne sprawy, ale w ogóle dochodzimy do samego sedna Jamesa, do jego dwuznacznej, zakłamanej seksualności, do jednego z wielkich tematów jego życia: stłamszonego homoseksualizmu. Gdyby miał się do niego publicznie przyznać, pewnie by to, jak Miles, przypłacił życiem. I, po długich walkach, stwierdziłem, że trzeba nieco Jamesa wyemancypować - po pierwsze, dlatego że w czasach wiktoriańskiej pruderii mógł napisać mniej niż dziś, a więcej zostawić domyślności świadomych czytelników, równocześnie bardziej wyczulonych na tego typu tropy. A po drugie, dlatego że dla mnie to jest jakaś niesamowita wprost sytuacja $\mathrm{z}$ tym wyznaniem, po którym odpędzony 
upiór Quinta powraca i go zabiera. Tu nie chodzi o to, że z kolegami, których lubił, świntuszył po kiblach, opowiadając pieprzne dowcipy. To jest wyznanie fundamentalne.

\section{Czy tłumacząc, opierał się Pan na jakichś opracowaniach czy analizach The Turn of the Screw?}

Tak, oczywiście, to jeden z ważnych tekstów kultury światowej przełomu XIX i XX wieku, do tego typu pracy należy się przygotowywać. Na szczęście teraz dostęp do opracowań, począwszy od tekstu Wilsona ${ }^{1}$ i wcześniejszych, a na nowościach kończąc, jest stosunkowo latwy.

A czy zaglądał Pan do komentarzy samego Jamesa? On nieco ten tekst postponowal, określając go jako „potboiler” albo najwyżej „an amusette to catch those not easily caught”.

Nie zawsze należy się przejmować tym, co mówili autorzy; Flaubert ponoć za najważniejsze swoje dzieło uważał Kuszenie św. Antoniego, a Hemingway pogardliwie mówił o Starym człowieku i morzu, że potrzebował na szybko pieniędzy, więc popełnił taki kawałek. W przypadku Jamesa mogło to zresztą wynikać po prostu z kokieteryjności, której nie był pozbawiony.

The Turn of the Screw to utwór wyjątkowo otwarty, ale oczywiście istnieją pewne utarte (choć często sprzeczne ze sobą) interpretacje. Na ile kierowały Panem w przekładzie? Do której się Pan osobiście skłania, a które musiał Pan niejako podtrzymywać wbrew sobie (choć nie wbrew tekstowi), by zachować otwartość interpretacyjną? Skąd w Pana odczytaniu biorą się duchy?

Wiadomo, że są dwie główne grupy interpretatorów, zjawowcy, którzy wierzą w obecność upiorów panny Jessel i Quinta, oraz niezjawowcy, którzy uważają, że wszystko dzieje się w głowie guwernantki. Przełomowy w interpretacji książki był pomysł Edmunda Wilsona z jego tekstu z 1934 roku, który wprawdzie nie był pierwszym wystąpieniem niezjawowców, ale zyskał duży rozgłos i wszedł do kanonu odczytań Jamesa. Według Wilsona to historia stłamszonej seksualności młodej kobiety na progu życia, w którym seks będzie jej społecznie jeśli nie zakazany, to w każdym razie trudno dostępny. Jest córką szalonego, jak się zdaje, ojca i faktycznie rozbudza w sobie osobliwie żarliwe uczucia do zdecydowanie niezainteresowanego nią chlebodawcy. Wszystko to składa się na stopniowo narastającą histerię.

Zasadniczym dla mnie problemem tej interpretacji jest fragment, w którym guwernantka rozmawia z panią Grose i, wedle Wilsona, wszystkie szczegóły ubioru i wyglądu Quinta bierze od swojej rozmówczyni. Ale tak nie jest. Guwernantka musiała widzieć Quinta - lub kogoś innego, tu możemy gdybać - bo sama z siebie podaje takie drobiazgi jak rudy kolor włosów i nieco ciemniejszy odcień brwi, a nawet to, że brwi zakreślają wysokie łuki. Co, prawdę mówiąc, wydaje się dość dziwne, zważywszy, że widzi zjawę z bardzo daleka, na wieży Bly, no ale mniejsza z tym, przyjmijmy, że ma sokoli wzrok. Zauważa, że nieznany mężczyzna ma na sobie cudze ubrania. Wszystko to są rzeczy, które ona mówi pani Grose, a nie odwrotnie. I dopiero na to pani Grose odpowiada, że to ubrania pana, a postać to Quint.

\footnotetext{
1 Chodzi o esej Edmunda Wilsona The Ambiguity of Henry James z 1934 roku, później rozbudowany w wydaniu z 1938 roku.
}

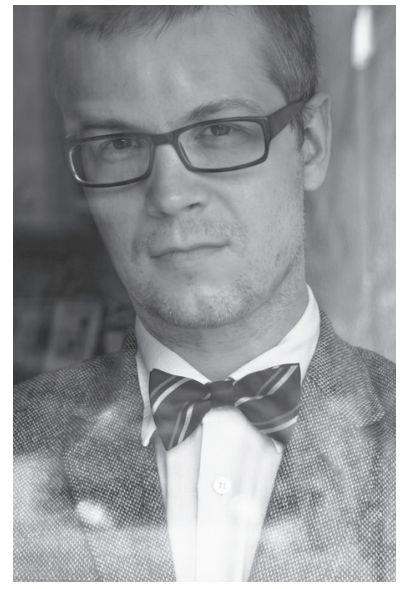

Jacek Dehnel. Fot. Cezary Rucki 
To, co wydaje mi się wyjątkowe ciekawe, to źródło pomysłu Wilsona, o którym pisze w tekście: otóż sam miał w dzieciństwie guwernantkę, która okazała się z czasem, ku przerażeniu całej rodziny, kompletnie szalona, co skłoniło go do takiej właśnie interpretacji. Możemy to sobie pociągnąć dalej i zauważyć, że to jego własna trauma z dzieciństwa kazała mu ujrzeć szaloną nauczycielkę tam, gdzie mamy do czynienia z opowieścią o duchach, bowiem dla niego szalona nauczycielka jest w istocie bardziej przerażająca niż upiór Quinta.

Jedną z pierwszych reakcji guwernantki na napotkanie zjawy (albo „zjawy”) jest przywołanie skojarzeń z powieścią gotycką. W tekście wielokrotnie pojawiają się nawiązania do literatury i ukształtowanych przez nią wyobrażeń. Czy w jakiś sposób nawiązywał Pan do stylu takich powieści w ich polskich wydaniach?

Wydaje mi się, że językowo powieść gotycka jest na tyle oswojona, że zarówno tłumacz, jak i czytelnik mają ją gdzieś z tyłu głowy, w różnych redakcjach - i nie chodzi tu tylko o zamczysko i duchy, ale i o całe frazy obiegowe, z których James czasem robi użytek. Równocześnie jednak jego składnia jest tak szczególna, tak osobliwa, że nie widzę powodu, żeby na przykład nabić sobie głowę przekładami powieści gotyckich, najlepiej z lat 90. XIX wieku, i je imitować - bo to nie byłby już język Jamesa, tylko jakiś pastisz autorów oryginalnych i ich tłumaczy sprzed wielu dekad. James posługuje się raczej pewnymi utartymi i łatwo rozpoznawalnymi „przyprawami”, sprawiając, że czytelnik czuje się w miarę bezpiecznie w tej formie, odbiera ją jako coś znajomego, niezaskakującego, choć oczywiście tekst jest pod wieloma względami nieznajomy i zaskakujący. On tylko sprytnie udaje znaną formę.

Czy były frazy lub fragmenty, nad którymi spędził Pan wyjątkowo dużo czasu? I odwrotnie, czy jakiś pomysł pojawil się od razu?

Tak, oczywiście, były nawet kawałki, które konsultowałem z kilkoma native speakerami, ludźmi obytymi nie tylko od urodzenia w angielszczyźnie, ale i specyficznie w literaturze pięknej, a mimo to słyszałem czasem: „No nie wiem, może być tak albo tak, to jest James, ja go czasem nie rozumiem, czasem nikt go nie rozumie, to są strasznie dziwne zdania”.

Skoro jesteśmy już przy tych frazach z powieści gotyckiej: oczywiście pani Grose zwraca się do guwernantki miss i oczywiście jest to nieprzetłumaczalne, bo w polszczyźnie musiałaby powiedzieć albo panienko, a tak mogłaby się zwracać do parę lat starszej Flory, a nie do nauczycielki, albo panno... no właśnie. Panno Smith, panno Jones, panno Newman? W filmach dostawała nazwisko: w The Innocents to Miss Giddens, w adaptacji z 1974 to Miss Jane Cubberly². Ale przecież tłumacz nie może sobie wziąć nazwiska z adaptacji filmowej, skoro autor z takim wysiłkiem, celowo, jak sądzę, omija imię i nazwisko bohaterki. A zatem w moim przekładzie pani Grose mówi do niej pani, choć panno Giddens brzmiałoby znacznie bardziej jak z typowej powieści grozy, dziejącej się w angielskiej posiadłości.

Jak organizuje Pan swój warsztat tłumacza? Jak wyglądała Pana praca nad Jamesem? Tłumaczy Pan z książki, wydruku, pliku?

Tłumaczyłem z pliku wordowskiego, nadpisując polski tekst na angielskim; jeśli nie miałem na coś pomysłu, zostawiałem, wytłuszczone, w oryginale i stopniowo, przy kolejnych podej-

2 The Innocents, reż. J. Clayton (1961), The Turn of the Screw, reż. D. Curtis (1974). 
ściach, cyzelowałem. Ale to, jak sądzę, są sprawy mało istotne. Najważniejsze rzeczy w tłumaczeniu dzieją się w głowie, nie na klawiaturze czy w plikach, to są tylko odpryski.

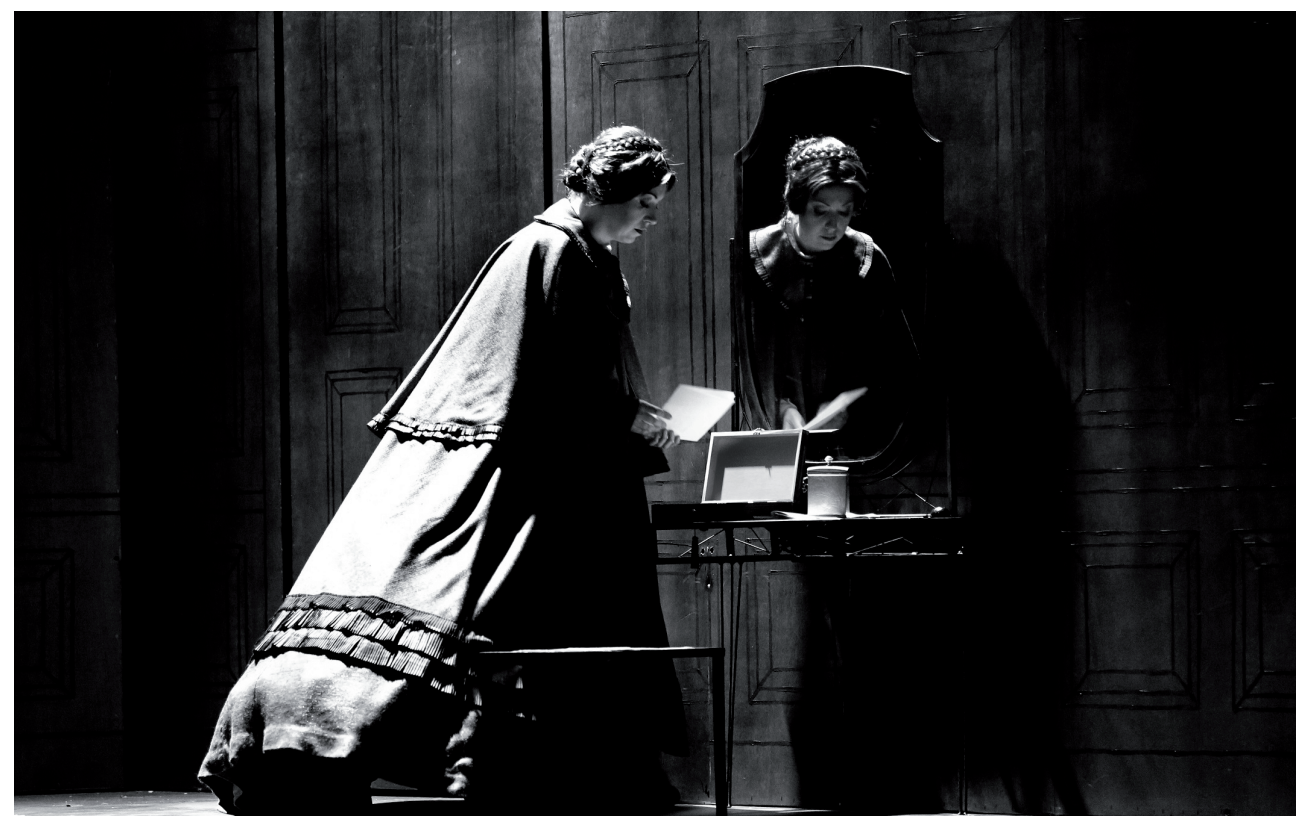

Dokręcanie śruby. Fot. Marek Grotowski

Czy w rozszyfrowywaniu języka Jamesa pomagały Panu jakieś słowniki albo narzędzia?

Żaden specyficzny słownik Jamesowski, ale oczywiście tam, gdzie zawodziły zwykłe słowniki, szukałem na inne sposoby: wypytywałem native speakerów, choć można sobie zadać pytanie, czy ktokolwiek jest native w języku Jamesa poza samym Jamesem. Wiele fraz poddawałem próbie Google’a: to, co czasem wydawało mi się jakimś rzadkim, nieznanym mi idiomem, okazywało się wynalazkiem Jamesa; kiedy indziej odnajdowałem to w jakimś innym tekście z epoki, w innej całości, która wyjaśniała mi znaczenie. Czasem dzięki jakiejś frazie trafiałem do rozmaitych opracowań naukowych, które wyjaśniały sens danej metafory - albo, po nitce do kłębka, jakiś inny trudny fragment tekstu.

Jakie najważniejsze aspekty powieści chciał Pan wydobyć, decydując się na zmianę tytułu w stosunku do przekładu Pospieszały? Jaka była reakcja wydawcy i redakcji? $\mathrm{Z}$ redakcją i wydawcą mieliśmy w tej kwestii różnicę zdań. Był znaczny opór. Tymczasem dla mnie pozostawianie „W kleszczach lęku” w ogóle nie było opcją; pierwszy impuls, przed wielu laty, kiedy po raz pierwszy zechciałem to przekładać - a byłem jeszcze w liceum to właśnie ten koszmarny polski tytul, który brzmi jak banalny tytuł powieści groszowej. Kleszcze lęku, kły przeznaczenia, skowyt duszy i tak dalej. Moja koleżanka z kolei miała inne skojarzenia i mówiła „w kleszczach lęku, w komarach udręku”.

Wahałem się pomiędzy obrotem śruby a dokręcaniem śruby - tytułem, który brzmi wcale nie gotycko, przeciwnie: technicznie, sucho, w czym wyraża się również przerażająca metodyczność tej książki. Bo przecież ona dokładnie na tej zasadzie jest zbudowana - stopnio- 
wego dokręcania gwintu, jak w torturze hiszpańskich trzewików: guwernantka stopniowo widzi i pojmuje sprawy coraz bardziej przerażające i równolegle stopniowo popada w histerię. Stanęło na dokręcaniu, a nie obrocie, bo w polszczyźnie mamy już ten związek frazeologiczny. Fiskus, rząd czy policja dokręca lub przykręca śrubę podatków, inwigilacji czy mandatów. Nie wszyscy tłumacze The Turn of the Screw mają takie udogodnienie w języku, na który tłumaczą.

Spory zaszły tak daleko, że redaktorka - z którą poza tym współpraca układała mi się, przyznać muszę, bardzo dobrze - posunęła się do zmieniania oryginalnych metafor Jamesa. Bo te obroty śruby pojawiają się przecież trzykrotnie w tekście: pod koniec, gdzie czytamy o „kolejnym obrocie” czy też „dokręcaniu śruby ludzkiej przyzwoitości”, oraz dwa razy na początku. W rozmowie pada zdanie, że dziecko w historii o duchach to „obrót”, „dokręcenie śruby” grozy, a dwójka dzieci to „dwa obroty”. I redakcja, niezgadzająca się z moim tytułem, zmieniła to na „wzmacnianie efektu” i „potęgowanie go w dwójnasób”. A ja bardzo takich operacji nie lubię i odpisałem dość ostro, acz z najgłębszym przekonaniem: „Chciałbym, żeby było to jasno powiedziane: redaktor poprawia moje pomyłki w przeniesieniu tekstu Jamesa do polszczyzny. Natomiast tekst oryginału miał swoją redakcję w roku 1898, ta praca została zakończona i obecna redakcja nie jest od tego”.

Równocześnie jednak muszę powiedzieć, że praca nad tekstem Jamesa była ogromnie trudna i pani redaktor wyświadczyła mi wielką przysługę swoimi wnikliwymi uwagami, za co jestem jej bardzo wdzięczny. Ale dokręcania nie odpuściłem, bo to była dla mnie sprawa zasadnicza, konsultowana zresztą z wieloma osobami.

Jednak sam James majstrowal przy swoim tekście, poprawiał go, komentował w przedmowie do wspomnianego już wydania nowojorskiego z 1908 roku. Czy źródłem było właśnie to wydanie poprawione?

Nie, ja akurat tłumaczyłem wedle tekstu z pierwszego wydania. Opinie co do tego, która wersja jest lepsza, są różne.

Jak widać, wbrew pozorom, przekład to rezultat pracy, decyzji i wpływów wielu osób. Kto, oprócz Pana, miał tu najwięcej do powiedzenia, i jak wpłynął na cały proces?

Wspomniana już pani redaktor, Magdalena Moltzan-Małkowska, doświadczona tłumaczka, również Jamesa, która miała z nim nieporównanie więcej do czynienia niż ja i uchroniła mnie od niejednej grubszej niezręczności. Mnóstwo pomógł mi mój chłopak, Piotr Tarczyński, który żadnej chyba mojej książki nie czytał tak wnikliwie, bo jednak lektura to jedno, a kolacjonowanie to drugie, i zaproponował mnóstwo bardzo grackich rozwiązań, wyłapał też sporo pomyłek. A pewnie i tak trochę ich zostało. No i parę innych osób, z którymi rozważaliśmy, czy obrót, czy dokręcanie.

I jeszcze poprzednik. Seria przekładowa to specyficzne wyzwanie. Widmo poprzedniego przekładu w pewnym sensie „nawiedza” nowego tłumacza. Jak było w tym przypadku? Chęć rywalizacji? Poprawienia poprzednika? Lęk przed wpływem? Czy przed przystąpieniem do pracy czytał Pan tłumaczenie Pospieszały, czy przeciwnie, starał się tego unikać?

Lektura wersji Pospieszały, kupionej w sopockim antykwariacie w roku 1998 albo 1999 to w ogóle powód, dla którego już wtedy zachciałem przełożyć The Turn of the Screw na nowo. 
Bo, począwszy od tytułu, byłem gruntownie czytelniczo niezadowolony z tego tłumaczenia, które wydawało mi się potwornie kwadratowe, nieforemne. Ale nie wiem, może czytelnicy moje uznają za bardziej nieforemne, trudno powiedzieć, trzeba by ich pytać. Plotki głoszą, że powstaje trzecie ${ }^{3}$. I bardzo dobrze, niech James żyje.

Czy są jakieś kwestie, w których zdecydowanie chciał się Pan od Pospieszały odróżnić? Jaki, Pana zdaniem, najważniejszy błąd udało się naprawić?

Nie wiem, czy poza tytułem są jakieś wyróżniające się błędy, błędy kardynalne. To raczej suma rozmaitych drobnych pominięć, przesunięć znaczeniowych, rzeczy, które odbieram jako niezgrabne, nieudane i tak dalej. W tym sensie chciałem się odróżnić - nie dlatego, że lęk przed wpływem i tak dalej; żadne tam wielkie miotające mną uczucia, ja po prostu tego jego tłumaczenia bardzo nie lubię. Tak po ludzku, po czytelniczemu nie lubię i tyle.

Czy podobnie zależy Panu na jakichś innych utworach Jamesa? Planuje Pan jeszcze jakieś przekłady tego autora?

Nie, czemu? James jest tłumaczony od wielu lat, nierzadko w bardzo udany sposób; nie zgadzałem się fundamentalnie z $W$ kleszczach lęku, ale nie mam żadnego całościowego projektu translatorskiego.

\section{Jak Pan w ogóle trafił do Jamesa? Czyżby przez Balzaca?}

Jak na mnóstwo innych książek: leżał w antykwariacie. Bo wprawdzie był też w domowej bibliotece, w serii Nike, ale do tego dogrzebałem się dopiero po lekturze The Turn of the Screw. Zaczęło się od tej powiastki grozy w złym przekładzie, czyli chyba dość nietypowo. Pamiętam potem zachwyt The Aspern Papers, ale tam tłumaczenie nie budziło we mnie oporu. A potem to się już potoczyło, nie tylko książkowo zresztą, bo są przecież i ciekawe adaptacje filmowe Jamesa, jest James w operze, w dalszych przetworzeniach literackich, na przykład w The Line of Beauty Alana Hollinghursta. Pojawił się nawet jako postać - wnosząca ze sobą do narracji Jamesowski styl - w Hotel de Dream, powieści Edmunda Whitea, którą przełożyłem z Piotrem Tarczyńskim.

W przeciwieństwie do przekładu Pospieszały, w Pana przekładzie pojawia się druk rozstrzelony. Jak jego zastosowanie wpływało na przekład?

To po prostu kwestia skorzystania z rozwiązań edytorskich wydania, z którego tłumaczyłem. Jedna z paru możliwości podkreślania słów. Nie sądzę, żeby to miało istotny wpływ na całość.

Od kogo pochodzą przypisy: od Pana czy od redakcji? Czy kusiło Pana, by dodać do tekstu jakiś wstęp czy posłowie?

Przypisy są moje. Od premiery książki minęło już blisko sto dwadzieścia lat, a w dodatku dzieli nas przepaść różnic kulturowych, pewne rzeczy należało, jak sądzę, doprecyzować czy wyjaśnić.

O ile pamiętam, nie było takiej koncepcji, żeby pisać wstęp czy posłowie. Trochę szkoda. Bo była to okazja, żeby ktoś - niekoniecznie ja - napisał zgrabną historię recepcji tej minipo-

\footnotetext{
3 Wywiad przeprowadzono przed ukazaniem się numeru „Literatury na Świecie” 05-06/2016.
} 
wieści i nakreślił główne osi sporów między interpretatorami, może też historię adaptacji: operowych, filmowych, telewizyjnych. Ale cóż, wszystko przed nami.

Jak wyobraża Pan sobie odbiorcę tego przekładu? Kim jest i czego oczekuje po tej powieści?

Ja nie stawiam czytelnikom warunków wstępnych. Ani jako autor, ani jako tłumacz. Każdy, kto chce sięgnąć po tę czy inną książkę, jest mile widziany.

Ja już skorzystałam. Bardzo dziękuję za wywiad!

Wywiad przeprowadziła Dorota Guttfeld*

* Adiunkt w Katedrze Filologii Angielskiej na Wydziale Filologicznym Uniwersytetu Mikołaja Kopernika w Toruniu, w pracowni przekładoznawstwa. Interesuje się problemami przekładu literackiego i audiowizualnego oraz anglojęzyczną literaturą fantastyczną. E-mail: gutt@umk.pl. 